\title{
Konsep Musyawarah dan Ganti Rugi Dalam Pengadaan Tanah Untuk Kepentingan Umum Prespektif Hukum Islam
}

\author{
Irfan Papalia \\ irfanpapalia@yahoo.com
}

\begin{abstract}
This study examined, first, the concept of deliberation in land procurement for the interest of public based on Islamic law and, second, the concept of compensation in land procurement for public development according to Islamic law. The answers were found though a normative juridical approach. The results showed that, first, Islam put forward the concept of deliberation for consensus as an absolute term in land procurement for the interest of the public. The concept of deliberation in land acquisition can accommodate the demand of the two parties, particularly the need to obtain justice and to avoid conflicts. Second, considering that the origin of land ownership is a mandate, the government should settle the compensation through deliberation, which refers to the concept of buying and selling with the bargaining principle. Islamic law justifies the transfer of land use rights as long as it is accompanied by compensation. The principle of compensation used is the sale and purchase law because the fundamental norms in the Qur'an and hadith are more general, especially in mu'amalah matters.
\end{abstract}

Keywords: Concept of deliberation and compensation of land acquisition (perspective of Islamic law)

\begin{abstract}
Abstrak
Permasalahan yang akan diteliti dalam penelitian ini yaitu, pertama, konsep musyawarah dalam pengadaan tanah untuk kepentingan umum menurut Hukum Islam. Kedua, konsep ganti kerugian dalam pengadaan tanah bagi pembangunan untuk kepentigan umum menurut Hukum Islam. Cara untuk menemukan jawaban atas kedua masalah tersebut, maka dilakukan dengan menggunakan yuridis normatif. Hasil penelitian menyimpulkan, pertama, Islam mengedepankan konsep musyawarah untuk mufakat sebagai syarat mutlak dalam hal pengadaan tanah bagi kepentingan umum. Konsep musyawarah dalam pengadaan tanah dapat mencapai keinginan antara kedua bela pihak, terutama keinginan untuk mendapat keadilan, dan menghindari konflik. Kedua, mengingat bahwa asal kepemilikan tanah adalah amanat maka pemerintah dalam menetap ganti kerugian dengan jalan musyawarah yang merujuk pada konsepsi jual beli dengan prinsip tawar menawar. Hukum Islam membenarkan pengambilan hak-hak atas tanah namun disertai dengan ganti rugi. Prinsip ganti rugi yang dipakai adalah hukum jual beli, oleh karena norma-norma dasar yang terdapat dalam Alquran dan hadis masih bersifat umum terutama dalam bidang mu'amalah.
\end{abstract}

Kata-kata Kunci: Konsep musyawarah; ganti rugi pengadaan tanah (prespektif hukum Islam) 


\section{Pendahuluan}

Cita-cita ideal yang terkandung di dalam konsepsi hak menguasai negara atas tanah adalah menempatkan negara sebagai sentral yang mengatur dan memanfaatkan kekayaan negeri untuk kemakmuran rakyat. Untuk mencapai cita-cita ini dengan tegas mengemukakan adanya sebuah negara yang kuat, karena menjadi sentral atau pusat dari segala hal, paling tidak dalam hal ini dengan segala persoalan agraria khususnya tanah. ${ }^{1}$ Tanah mempunyai arti yang sangat strategis bagi kehidupan manusia di muka bumi, hampir seluruh sektor kehidupan manusia bergantung dan bersumber pada tanah, baik sebagai tanah pertanian, tanah pemukiman, tempat usaha, tempat peribadatan dan juga termasuk pada sektor pembangunan.

Tanah dan pembangunan merupakan dua entitas yang berbeda namun tidak dapat dipisahkan. Secara sederhana dapat dikatakan bahwa tidak akan ada pembangungan tanpa tanah. ${ }^{2}$ Semakin tinggi pembangunan di satu negara maka secara otomatis sangat memerlukan tanah yang begitu luas. Kegiatan untuk keperluan pembangunan tersebut memberi peluang terjadinya pengambilalihan tanah untuk proyek, baik untuk kepentingan negara/kepentingan umum maupun untuk kepentingan bisnis, dalam skala besar maupun kecil. ${ }^{3}$

Pada praktik pengadaan tanah, hak-hak atas tanah dapat diambil oleh pemerintah dengan tujuan pembangunan untuk kepentingan umum. Pengambilalihan tanah sudah tentu berkaitan dengan landasan filosofis dan tujuan yang membolehkan pengambilalihan tersebut, mengingat tanah adalah instrumen ekonomis yang juga memiliki kandungan sosial-humanistik. Dengan demikian persoalan pertanahan dalam konteks aturan pengadaan tanah untuk kepentingan umum nampaknya akan terus menarik perhatian. Dikatakan demikian, karena di satu sisi aturan hukum pertanahan mampu menjaga kepemilikan seseorang atau insitusi tertentu, namun di sisi lain, dengan peraturan perundang-undangan tersebut seseorang atau insitusi tertentu dalam hal ini sebagai pemegang hak atas tanah sewaktu-waktu harus rela melepaskan kepemilikan tanahnya untuk

\footnotetext{
${ }^{1}$ Mukmin Zakie, Kewenangan Negara Dalam Pengadaan Tanah Bagi Kepentingan Umum Di Indonesia Dan Malasya, Cetakan Kedua, Buku Litera, Yogyakarta, 2013, hlm. 6

${ }^{2}$ Winahyu Erwiningsih, Hak Menguasai Negara Atas Tanah, Cetakan 1, Universitas Islam Indonesia, 2009, Yogyakarta, hlm. 270

${ }^{3}$ Bernard Limbong, Politik Pertanahan, Margaretha Pustaka, Jakarta, 2014, hlm. 272
} 
kepentingan umum. Menurut Djojodigono, ${ }^{4}$ pelenyapan hak milik pribadi dapat dibenarkan apabila memang benar-benar untuk kepentingan umum dan disertai penggantian yang patut. Namun, upaya ganti rugi belum berjalan dengan baik, sehingga selalu terjadi sengketa antara kedua bela pihak, baik pemerintah dan masyarakat. ${ }^{5}$

Masalah ganti kerugian menjadi komponen yang paling sensitif dalam proses pengadaan tanah. Pembebasan mengenai bentuk dan besarnya ganti kerugian sering kali menjadi proses yang panjang, dan berlarut-larut (time consuming) akibat tidak adanya kesepakatan di antara pihak-pihak yang bersangkutan.

Dalam konteks Islam, pengambilan tanah untuk kepentingan umum (maslahah amanah) pernah dilakukan oleh Khulafa' al-Rasyidin dan Khalifah Islam selanjutnya. Khalifa Umar bin al-Khattab telah diputuskan dalam kasus Jurir bin Abdullah Bajalil, di mana dalam kasus ini Jarir telah dijanjikan sebanyak satu perempat $(1 / 4)$ dari tanah di wilayah Iraq sekirannya tentara Islam dapat menakluki negeri itu. Peristiwa ini terjadi setelah peperangan Qadisiyyah yaitu setelah kematian Panglima Abu Ubaid. Tanah-tanah itu telah diberikan kepada Jarir dan tiga tahun kemudian Khalifah Umar R.A meminta supaya Jarir mengembalikan tanah-tanah itu karena orang-orang Islam telah bertambah secara besar-besaran. Jarir mengembalikan tanah-tanah itu dan Khalifah Umar R.A membayar dari (sebagai perampasan) perbendaharaan memberikan sebesar 80 dinar. $^{6}$

Berdasarkan ayat Al Qur'an, hadist Rasulullah dan Risalah Nabi Muhammad, serta para khulafa al-Rasyidin dapat dipahami bahwa menurut ajaran Islam, tetap dibenarkan adanya penggunaan tanah orang lain untuk kepentingan umum. Hukum Islam sangat menghormati hak milik orang lain, dan dengan menghargai secara wajar. Walaupun penggunaan untuk kepentingan umum, akan tetapi tidak di ambil begitu saja, melainkan dengan ganti kerugian yang wajar. Prosesnya

${ }^{4}$ GunaNegara, Rakyat dan Negara, Dalam Pengadaan Tanah Untuk Pembangunan, Cetakan Pertama PT. Tatanusa, Jakarta, 2008, hlm. 25

${ }^{5}$ Muhammad Yamin Lubis dan Rahim Lubis, Pencabutan Hak, Pembebasan, Dan Pengadaan Tanah, Cetakan Pertama, CV. Mandar Maju, Bandung, 2011, hlm. 80

${ }^{6}$ Amimuddin Salle, Hukum pengadaan tanah untuk kepentingan umum, Cetakan Pertama, Kreasi Total Media, Yoyakarta, 2007, hlm. 286 
adalah sesuai dengan aturan-aturan perniagaan yang berlaku dan dilakukan secara sukarela. $^{7}$

Islam juga mengajarkan tentang keadilan baik untuk masyarakat maupun untuk negara. Keadialan bagi masyarakat digambarkan ketika pemerintah sebagai pelakasana dari tugas negara dapat melakukan tanggung jawabnya dengan tidak mementingan kebutuhan negara saja, begitu pula sebaliknya. Persoalanya negara (pemerintah) lebih aktif dalam melaksanakan kegiatan yang termaksuk dalam wilayah hak masyarakat itu sendiri.

\section{Rumusan Masalah}

Berdasarkan hal-hal di atas, maka yang menjadi masalah dalam penelitian ini meliputi: pertama, bagaimana konsep musyawarah dalam pengadaan tanah untuk kepentingan umum menurut Hukum Islam? Kedua, bagaimana konsep ganti kerugian dalam pengadaan tanah bagi pembangunan untuk kepentingan umum menurut Hukum Islam?

\section{Tujuan Penelitian}

Berdasarkan hal-hal di atas, maka yang menjadi tujuan penelitian ini meliputi: pertama, mengetahui sejauh mana konsep musyawarah dalam pengadaan tanah untuk kepentingan umum menurut Hukum Islam. Kedua, mengetahui konsep ganti kerugian dalam pengadaan tanah bagi pembangunan untuk kepentingan umum menurut Hukum Islam.

\section{Metode Penelitian}

Metode adalah cara untuk menemukan jawaban atas kedua masalah tersebut. Cara penemuan jawaban tersebut sudah tersusun dalam langkah-langkah tertentu yang sistematis. ${ }^{8}$ Jenis penelitian yang digunakan adalah pendekatan yuridis normatif yaitu penelitian dengan menggunakan kajian pustaka yang berkaitan dengan masalah yang dibahas merujuk pada undang-undang serta aturan yang relevan. Pendekatan yang digunakan yaitu pendekatan perundang-undangan dan

\footnotetext{
${ }^{7}$ Ibid., hlm. 49

8 Soerjono Soekanto dan Sri Mamujidji, Penelitian Normatif (Suatu Tinjauan Singkat), Cetakan Pertama, Rajawali Press, Jakarta, 2003, hlm. 1
} 
konseptual yang merujuk pada peraturan perundang-undangan yang berlaku dan hukum Islam yang berkaitan dengan pengadaan tanah untuk kepentingan umum. Obyek dari penelitian ini adalah konsep musyawarah dan ganti rugi dalam pengadaan tanah unuk kepentingan umum dalam prespektif hukum Islam. Adapun sumber-sumber hukum yang peneliti gunakan terdiri dari tiga bagian yaitu bahan hukum primer, bahan hukum sekunder dan bahan hukum tersier. Bahan hukum primer yang digunakan dalam penelitian ini adalah peraturan perundang-undangan dan sumber hukum dalam hukum Islam meliputi, AlQur'an; Undang-Undang Dasar 1945; dan peraturan perundang-undangan yang mengatur mengenai penguasaan negara. Bahan hukum yang digunakan dalam membahas permasalahan ini adalah bahan yang memberikan penjelasan mengenai hukum-hukum primer seperti rancangan undang-undang, hasil-hasil penelitian atau pendapat para pakar/ulama yang berkaitan dengan pengadaan tanah untuk kepentingan umum. Metode analisa data peneliti yang dilakukan dalam penelitian ini adalah dengan metode deskriptif kualitatif. Metode deskritf kualitatif yaitu anilisis data dengan menggunakan pengujian yang didasarkan pada situasi yang sedang terjadi, sikap serta pandangan yang terjadi di dalam masyarakat, pertentangan 2 keadaan/lebih, hubungan antara variabel, perbedaan antar fakta, pengaruh terhadap suatu kondisi dengan menggunakan al-Qur'an, Hadist, maupun beberapa ketetapan ulama sebagai yang menjadi dasar pengujian dalam penelitian ini.

\section{Hasil Penelitian dan Pembahasan}

\section{Konsep Musyawarah dalam Pengadaan Tanah Menurut Hukum Islam}

Secara harfiah kata musyawarah berasal dari kata مشاورة adalah masdar dari kata kerja syawara-yusyawiru, yang berakar kata syin, waw, dan ra' dengan pola fa'ala. Struktur akar kata tersebut bermakna pokok "menampakkan dan menawarkan sesuatu" Dari makna terakhir ini muncul ungkapan "syawartu fulanan fi amri" (aku mengambil pendapat si Fulan mengenai urusanku). ${ }^{9}$ Musyawarah pada mulanya

9 Sohrah, "Konsep Syura dan Gagasan Demokrasi (Telaah Ayat-ayat Al-Qur'an)" Al-Daulah, Vol. 4, No. 1, Juni 2015, hlm. 203 
bermakna "mengeluarkan madu dari sarang lebah".10 Makna ini kemudian berkembang sehingga mencakup segala sesuatu yang dapat diambil atau dikeluarkan dari yang lain (termasuk pendapat). Karenanya, kata musyawarah pada dasarnya hanya digunakan untuk hal-hal yang baik. ${ }^{11}$

Sejalan dengan makna dasarnya, dalam Kamus Besar Bahasa Indonesia, musyawarah diartikan sebagai pembahasan bersama dengan maksud mencapai keputusan atas penyelesaian masalah bersama. Selain itu dipakai juga kata musyawarah yang berarti berunding dan berembuk. Oleh karena itu, unsur esensial dalam musyawarah adalah kesatuan pendapat di antara kedua belah pihak mengenai suatu persoalan.

Menurut Quraish Shihab, pada dasarnya syura (musyawarah) hanya digunakan untuk hal-hal yang baik. ${ }^{12}$ Di dalam al-Quran, ada tiga ayat yang akar katanya menunjukan keharusan bermusyawarah, yaitu (1) surat al-Baqarah [2] ayat 233, surat an-Nisa [4] ayat 34, (2) surat ali-Imran [3] ayat 159, dan (3) surat asy-Syura [42] ayat 38. Ayat-ayat tersebut menunjukan suatu perintah musyawarah sebagai kewajiban hukum bagi kaum muslim dalam memecahkan suatu persoalan keumatan. ${ }^{13}$

Sebagai ajaran yang paripurna, Islam telah menganjurkan musyawarah dan memerintahkannya dalam banyak ayat dalam al-Qur'an. Ia menjadikannya sebagai suatu hal terpuji dalam kehidupan individu, keluarga, masyarakat dan negara dan menjadi elemen penting dalam kehidupan umat. Ia disebutkan dalam sifat-sifat dasar orang-orang beriman di mana keislaman dan keimanan mereka tidak sempurna kecuali dengannya. Allah berfirman: "Dan (bagi) orang-orang yang menerima (mematuhi) seruan Tuhannya dan mendirikan shalat, sedang urusan mereka (diputuskan) dengan musyawarah antara mereka; dan mereka menafkahkan sebagian dari rezki yang kami berikan kepada mereka". (QS. as Syura: 38).

Oleh karena kedudukan musyawarah sangat agung, maka Allah memerintahkan Rasulullah untuk melakukannya. Allah berfirman: "Dan

\footnotetext{
${ }^{10}$ Dudung Abdullah, "Musyawarah Dalam Al-Qur'an (Suatu Kajian Tafsir Tematik)" Al-Daulah, Vol. 3, No. 2, Desember 2014, hlm. 245

${ }^{11}$ M. Quraish Shihab, Wawasan Al-Qur'an, Mizan, Bandung, 1996, hlm. 469

12 Ibid

${ }^{13}$ Muhammad Alim, Asas-Asas Negara Hukum Modern dalam Islam, Kajian Komprehensif Islam dan Ketatanegaraan, Cetakan I, LKIS, Yogyakarta, 2010, hlm. 160
} 
bermusyawaralah dengan mereka dalam urusan itu". (QS. Ali Imran: 159). Sebagaimana dengan perintah Allah SWT, maka Rasulullah menjalankan perintah tersebut. Hal demikian ketika dilakukan bermusyawarah dengan para sahabatnya, bahkan beliau adalah orang yang paling banyak bermusyawarah dengan sahabat. Beliau bermusyawarah dengan mereka di perang badar, perang uhud, perang khandaq, dan sebagainya. ${ }^{14}$ Beliau mengalah dan mengambil pendapat para pemuda untuk membiasakan mereka bermusyawarah dan berani menyampaikan pendapat dengan bebas sebagaimana di perang Uhud. Rasulullah telah merumuskan musyawarah dalam masyarakat muslim dengan perkataan dan perbuatan, dan para sahabat dan tabi'in para pendahulu umat ini mengikuti petunjuk beliau, sehingga musyawarah sudah menjadi salah satu ciri khas dalam masyarakat muslim dalam setiap masa dan tempat.

Pada masa pemerintahan Umar bin Khattab ada lembaga yang bernama "Ahl alhall wa al-'Aqd" atau lebih dikenal dengan sebutan Ahl al-syura. Lembaga Ahl al-syura pada masa itu oleh para sahabat digunakan sebagai media untuk memilih pengganti kepala negara dan bermusyawarah untuk merumuskan arah kebijakan negara. Anggotanya adalah para sahabat senior yang ditunjuk oleh khalifah untuk membantunya dalam merumuskan kebijakan dan menjalankan roda pemerintahan.

Musyawarah pengambilan keputusan dalam bentuk referendum yang melibatkan semua anggota masyarakat atau rakyat di satu negara, juga bisa dinilai dalam bentuk lain dari musyawarah, hal ini tampak dalam Piagam Madinah yang di antara diktum menegaskan perlunya bermusyawarah untuk saling memberi nasehat serta saran dalam kebaikan dan melakukan kerja sama dalam bidang pertanahan. ${ }^{15}$

Pembahasan mengenai prinsip-prinsip pelaksanaan musyawarah dalam pengadaan tanah masih jarang ditemukan, hal ini dikarenakan belum adanya praktik musyawarah yang menyeluruh dan berkesinambungan mulai dari kehidupan bermasyarakat, berbangsa, dan bernegara. Meski demikian, ada banyak

\footnotetext{
${ }^{14}$ Akhmad Saufan, "Strategi dan Diplomasi Perang Rasulullah" Jurnal Lektur Keagamaan, Vol. 13, No. 1, 2015, hlm. 118

15 Suruh Roiqoh, "Pengadaan Tanah Untuk Kepentingan Umum (Kajian Perbandingan Antara Hukum Islam dalam Konsep Maslaha Mursalah dan Undang-Undang Nomor 2 Tahun 2012)”, Tesis pada Fakultas Hukum Universitas Islam Indonesia, Yogyakarta, 2013, hlm. 72
} 
pemikiran dan pembahasan mengenai musyawarah sebagai suatu prinsip yang harus ditegakkan dalam kehidupan bermasyarakat dan berbangsa termasuk dalam ihwal tata kelola pertanahan serta pengadaan tanah untuk kepentingan umum. Beberapa prinsip tersebut adalah sebagai berikut.

Pertama, keridhaan yaitu suatu kemauan untuk kebaikan bersama yang tidak bertentangan dengan perintah Allah Swt. Hal ini dapat dilihat pada ayat pertama dalam pembahasan sebelumnya yaitu Q.s. Al-Baqarah ayat 233, di mana Allah memberikan petunjuk apabila dalam suatu keluarga sudah ada keridhaan di antara keduanya dan bermusyawarahlah.

Kedua, hati yang lemah lembut (bersih) lawan dari berhati keras. Prinsip ini haruslah ada, hati yang lemah lembut yaitu yang tidak menaruh kedengkian dan kebencian antara satu sama lainnya, dalam musyawarah perilaku ini akan terlihat pada saat berbicara atau menyampaikan pendapat atau sebuah gagasan. Oleh karenanya, apabila musyawarah dilaksanakan tidak berdasarkan hati yang lemah lembut (bersih) sebagai rahmat dari Allah SWT, maka mustahillah akan dapat terjadi kemufakatan.

Ketiga, saling memaafkan dan memohonkan ampun kepada Allah SWT. Dalam musyawarah pasti akan sering terjadi perbedaan pendapat mengenai suatu pembahasannya, maka antara sesama anggota yang terlibat di dalam musyarawah apabila ada yang merasa tersinggung akibat ucapan maupun pemikiran, maka mestilah siap untuk saling memaafkan dan memohon ampunan kepada Allah SWT.

Keempat, mematuhi perintah Allah SWT dan mendirikan sholat. Berdasarkan prinsip yang keempat ini menunjukan bahwa dalam praktik musyawarah untuk mengambil suatu keputusan harus didasarkan atau tidak boleh bertentangan dengan perintah Allah SWT. Makanya, orang-orang yang bermusyawarah dalam menetapkan suatu aturan atau hukum untuk kehidupan bersama harus senantiasa didasarkan kepada hukum-hukum Allah SWT. Kelima, mufakat, segala keputusan yang akan ditetapkan dalam suatu permusyawaratan harus merupakan kemufakatan dari seluruh anggota yang terlibat di dalam musyawarah. Mufakat adalah anggota musyawarah menerima hasil musyawarah yang akan diputuskan dan ditetapkan untuk dilaksanakan bersama-sama. 
Adapun keputusan yang diambil tersebut tidaklah boleh bertentangan dengan prinsip-prinsip hukum Islam, dalam konteks kaidah-kaidah utama yang tertuang di dalam tujuan hukum menurut syara' yang disebut dengan Adhdhararul, yaitu: memelihara agama, memelihara jiwa, memelihara akal, memelihara keturunan, memelihara harta dan kehormatan. ${ }^{16}$

Dalam Al-Qur'an menjelaskan tentang pelaksanaan musyawarah sebagai jalan untuk menyelesaikan persoalan kepentingan umum, yang di dalamnya adalah kepentingan rakyat, bangsa dan negara. Dalam QS al-Syura ayat 38, dianjurkan bahwa setiap persoalan yang menyangkut masyarakat atau kepentingan umum harus dimusyawarahkan. Oleh karena itu, Rasulullah selalu mengambil keputusan setelah melakukan musyawarah dengan para sahabatnya.

Allah menggambarkan praktik musyawarah dengan kisah-kisah yang diungkapkan dengan begitu memukau. Kisah yang tentunya sebagai bentuk pengajaran bagi umat manusia. Hal ini bertujuan agar manusia mendapatkan cahaya untuk mengetahui apakah jalan yang dilaluinya benar atau salah. Oleh karenanya, dapat disimpulkan bahwa memahami kisah-kisah dalam Al-Qur'an adalah bentuk edukasi kepribadian.

Melalui musyawarah pengadaan tanah untuk kepentingan umum dapat ditemukan suatu jalan keluar yang sebaik-baiknya semua pihak mengemukakan pandangan dan pikiran mereka yang wajib didengar secara bersama sehingga dalam keputusan dapat mempertimbangkan yang objektif dan bijaksana untuk memberikan rasa keadilan.

Musyawarah dalam pengadaan tanah untuk kepentingan umum terhadap tanah seseorang yang diambil oleh negara, selalu terfokus pada konsep yang sudah dibangun oleh Rasulullah SAW saat beliau menjabat, dan juga sahabat kekhalifahan dengan selalu berpedoman pada Al-qur'an.

Pada saat Rasulullah SAW melanjutkan perjalanan ke Madinah, dengan menggunakan unta, beliau berhenti (mendekam) di atas sebidang tanah milik dua orang anak yatim yang bernama Sahal dan Suhail, keduannya anak dari Amr bin

${ }^{16}$ Fuad Hasbi Ash-Shiddieqy, ed., Falsafah Hukum Islam, PT. Pustaka Rizki Putra, Semarang, 2001, hlm. 169. 
Amarah di bawah pemelihraan As'ad ibnu Zarzarah. Tempat itu adalah penjemuran kurma milik dua orang anak laki-laki yatim itu. Beliau kemudian dipersilahkan oleh Abu Ayub Al Ansari untuk tinggal dirumahnya. Setelah beberapa bulan menetap, beliau merencanakan untuk membangun mesjid. Tempat yang dipilih adalah bekas mendekamnya unta beliau. Rasulullah memanggil kedua anak yatim tersebut dengan maksud ingin membeli tanah itu guna tempat mendirikan masjid. Kedua anak itu bertahan dan tidak akan menjual tanahnya kepada Rasulullah, kecuali hanya bersedia mewakafkannya. Akan tetapi beliau juga bertahan tidak mau mengambil begitu saja tanah itu, walaupun dalam bentuk wakaf. Beliau tidak mau mengambil tanah itu sebagai pemberian, tetapi hendak membelinya. Pada akhirnya, beliau berhasil membeli tanah itu melalui cara musyawarah dari tangan kedua anak yatim itu dengan harga yang disepakati yaitu, sebesar sepuluh dinar, dan yang membayarnya adalah Abu Bakar. ${ }^{17}$ Dari uraian ini, dapat dipahami bahwa Rasullah, tidak mengambil begitu saja tanah seseorang, melainkan dengan membelinya dengan harga yang wajar, walaupun sesungguhnya orang tersebut menyerahkan secara cuma-cuma karena mereka sadar bahwa tujuannya adalah guna kepentingan umum. ${ }^{18}$

Islam tidak pernah melakukan tindakan yang merugikan pemilik baik menyakut harta tanahnya maupun harta-harta lainnya. Dengan menghindari kerugian antara satu pihak maka musyawarah harus dilakukan berdasarkan tujuan syari'at yaitu terpeliharanya hak atau jaminan dasar manusia yang meliputi kehormatan, keyakinan jiwa, akal, agama, dan ketururnan dan kesalamatan hak milik. Masalah yang diselesaikan harus sesuai dengan ketentuan yang telah diatur dalam fiqih Islam yaitu:

1. Penentuan ganti rugi tersebut tidak menyelahi hukum syari'at Islam;

2. Harus sama ridha dan ada pilihan antara kedua bela pihak tanpa ada unsur paksaan dan tipuan dari pihak lain;

3. Harus jelas tujuan agar tidak ada kesalapahaman di antara para pihak tentang apa yang telah dikerjakan di kemudian hari.19

\footnotetext{
17 Anwar Ibrahim, dkk., Status Tanah Masjid Harus Wakaf: Sudut Pandang Empiris dan Hukum Islam, Badan Wakaf Indonesia, Jakarta, 2012, hlm. xiii

18 Amimuddin Salle, Hukum Pengadaan Tanah Untuk Kepentingan Umum, Cetakan Pertama, Kreasi Total Media, Yogyakarta, 2007, hlm. 49

${ }^{19}$ Chairuman P, Hukum perjanjian dalam Islam, Sinar Grafika, Jakarta, 1994, hlm. 3
} 
Akhirnya, satu hal penting yang perlu diperhatikan dalam prinsip musyawarah ini ialah dari segi hukum Islam dibenarkan manusia melakukan musyawarah hanya dalam hal-hal yang ma'ruf atau kebaikan. Karena itu musyawarah dilarang untuk digunakan dalam hal-hal yang mungkar, misalnya dalam musyawarah menentukan ganti rugi pemerintah/instasi memiliki niat yang tidak baik di antaranya, tidak memberikan kesempatan kepada pemilik tanah untuk berbicara, meneror, membodohi. Kalaupun itu terjadi maka kegiatan itu tidak disebut musyawarah, tetapi melakukan "makar" atau "kesepakatan jahat oleh panitia pengadaan tanah". Tradisi itu dilanjutkan oleh keempat Khalifah yang menggantikan Rasulullah, yaitu Abu bakar, Umar, Usman, dan Ali. Misalnya masalah seleksi jabatan khalifah dipecahkan melalui musyawarah di antara tokohtokoh Madinah ketika itu yang pada umumnya adalah para Sahabat Rasul.

Pada masa kini musyawarah pengadaan tanah dapat dilakukan oleh panitia pengadaan tanah. Untuk menjamin kepastian hukum dalam pengadaan tanah maka musyawarah itu sendiri dibatasi selama 90 hari kalender, terhitung sejak tangggal undangan pertama disampaikan. Proses musyawarah diawali dengan proses-proses pendataan kepemilikan tanah, dari mana/pemegang hak, letak, luas dan sampai jenis kepemilikan tanah. Setelah proses dimaksud dianggap akurat, maka kegiatan selanjutnya adalah sosialisasi kepada para pemilik/pemegang hak atas tanah yang akan dikenakan pembebasan. Kegiatan sosialisasi merupakan kewajiban yang harus dilakukan dalam bidang apapun, termasuk dalam bidang pengadaan tanah untuk kepentingan umum.

\section{Konsep Ganti Rugi dalam Pengadaan Tanah Untuk Kepentingan Umum Menurut Hukum Islam}

Di dalam literatur peraturan perundang-undangan dan hukum Islam terdapat beberapa penyebutan terhadap ganti rugi yaitu dengan istilah ganti kerugian atau kompensasi. Iistilah ganti kerugian dalam peraturan perundangundangan sudah mulai dilakukan pada masa belum adanya pemerintahan, atau dalam masyarakat yang masih berbentuk suku-suku (tribal organization), bentukbentuk ganti rugi merupakan sesuatu yang biasa terjadi sehari-hari. Pada masa ini terlihat, sanksi ganti kerugian merupakan suatu tanggung jawab baik pribadi 
ataupun pemerintah dalam melakukan tindakan yang dapat merugikan orang lain. Begitupun dalam hukum Islam, istilah ganti rugi sudah dilakukan di masa pemerintahan Rasulullah ketika tanah-tanah yang sudah dilekati hak oleh masyarakat kemudian di ambil guna kepentingan sosial.

Ganti rugi adalah suatu kewajiban yang dibebankan kepada orang atau pemerintah yang telah bertindak melanggar hukum dan menimbulkan kerugian pada orang lain karena kesalahannya tersebut. Menurut Kamus Besar Bahasa Indonesia ganti rugi adalah uang yang diberikan sebagai pengganti kerugian atau pampasan. ${ }^{20}$ Ganti rugi dalam istilah hukum, sering disebut legal remedy, adalah cara pemenuhan atau kompensasi yang diberikan kepada pihak yang menderita kerugian dari akibat perbuatan pihak lain yang dilakukan karena kelalaian atau kesalahan maupun kesengajaan. ${ }^{21}$

Dasar hukum pelepasan atau penyerahan dan ganti rugi hak atas tanah menurut ajaran Islam yaitu sebagaimana telah dilaksanakan oleh Rasulullah Saw dan Khalifah Umar bin Khattab.

\section{a. Zaman Rasulullah}

Sebagaimana Rasulullah dan khalifah-khalifah pada Zaman Rasulullah, pernah melakukan dan melaksanakan pengadaan dan pelepasan hak atas tanah yaitu di saat Nabi akan mendirikan Masjid Nabawi, dengan cara membeli tanahtanah masyarakat dengan suatu peroses musyawarah dan kebijakan-kebijakan yang mengandung suatu keadilan. Pengertian "membeli" dipastikan akan menghasilkan suatu nilai yang lebih dapat dikatakan sebagai ganti untung yang diperoleh masyarakat dengan menjual tanah-tanah mereka walaupun sifat kepentingannya untuk kemaslahatan umat atau masyarakat, misalnya beliau telah membeli tanah penduduk (As"'ad bin Zurarah, tanah anak yatim dan sebagian kuburan musyrikin yang telah rusak)".22

20 WJS. Poerwadharminta, Kamus Besar Bahasa Indonesia. Pusat Bahasa Indonesia, Balai Pustaka, Jakarta, 2003, hlm. 475 289

${ }^{21}$ J.T.C. Simorangkir, Edwin Rudy, S.H. dan Prasetyo, J.T. Kamus Hukum, Aksara Baru, Jakarta, 1980, hlm.

${ }^{22}$ Nurhayati A, Studi Komparatif Ganti Rugi Atas Tanah Ditinjau Dari Prespektif Hukum Islam Dan Hukum Agraria Nasional (Studi Kasus Pelebaran Jalan Di Kota Medan), Program Pasca Sarjana Institut Agama Islam Negeri Sumatera Utrara Medan, 2014, hlm. 190 


\section{b. Pada masa Khalifah Umar bin Khattab ra.}

1) Sewaktu pelebaran Masjid Nabawi $17 \mathrm{H}$, Umar membeli seluruh dari property yang ada di sekeliling masjid kecuali rumah-rumah janda-janda Rasul untuk perluasan masjid. ${ }^{23}$

2) Umar membeli rumah Safwan bin Umaiyah untuk dijadikan bangunan penjara sebgai tempat tahanan bagi orang-orang yang melakukan tindak kriminal. ${ }^{24}$

Sejarah mencatat, Khalifah Umar bin Khattab telah membangun Masjidil Haram secara permanen pada 638 Masehi. Sejak zaman Khalifah Umar bin Khattab ra hingga 1988, masjid ini tercatat mengalami renovasi dan perluasan 10 kali. Mereka yang tercatat sebagai pemimpin program perluasan dan renovasi Masjidil Haram adalah Khalifah Usman bin Affan (648 M), Abdullah ibnu Zubair (685 M), Ali Walid ibnu Abdul Malik (709 M), Abu Ja"far al- Mansur al- Abbasi (755 M), AlMu'tadlid al- Abbasi (918 M), Al- Muqtadir al- Abbasi (918 M), Raja Abdul Aziz alSaud (1955 M), dan Raja Fadh ibnu Abdul Aziz al- Saud (1988 M). Setelah sepuluh kali renovasi dan perluasan, saat ini luas Masjidil Haram mencapai 328 ribu meter persegi.

Menurut Imam Syafi'i bahwa Pemerintah boleh saja mengambil alih pengelolaan atas tanah apabila dipandang menyangkut atau berkaitan dengan kemaslahatan (kepentingan) kaum muslimin. ${ }^{25}$

Islam memandang negara sebagai institusi yang mengelola masyarakat dalam suatu negara. Dasar inilah Islam memberikan hak dan kewajiban kepada Negara untuk mengatur hubungan antara individu dengan individu dan individu dengan masyarakat, demikian pula hubungan masyarakat dengan negara. Islam memberikan otoritas kepada Pemerintah dalam membuat regulasi tentang kebolehan pengambilalihan tanah didasarkan pada konsep maslahat ammah. Peraktek-peraktek pelaksanaan pelepasan hak atas tanah yang dimiliki masyarakat untuk pelebaran masjid maupun untuk kegiatan-kegiatan kepentingan masyarakat, seluruh pelaksanaan pengambilalihan atau pemindahan tanah yang

\footnotetext{
${ }^{23}$ Suyuthi, Tarikh Khulafa: Sejarah Para Khilafah, Terjemahan oleh Ali Nurdin, Qisthi Press, Jakarta, 2017.

24 Ibid

25 Nurhayati A, Studi..., Op., Cit., hlm. 192
} 
dilaksanakan pemerintah pada masa Rasulullah dan khalifah-khalifahnya dengan cara membeli tanah-tanah yang dimiliki atau dikuasai masyarakat.

Demikian juga pada masa Pemerintahan Bani Umaiyah pada 86 H s/d $96 \mathrm{H}$ atau $705 \mathrm{M}$ yang dipimpin oleh Khalifah al-Walid bin Malik yang memerintahkan untuk membebaskan tanah-tanah di sekeliling Masjid Nabawi untuk pelebaran mesjid tersebut dengan cara ganti rugi atau jual beli, serta pelaksanaan ganti ruginya berupa uang karena bersifat jual beli antara penguasa setempat dengan penduduk.

Ganti kerugian yang dilakukan melalui proses jual beli yaitu pelaksanaan dilakukan dengan prinsip tawar menawar. Pembayaran ganti kerugian diberikan segera mungkin kecuali jika penerima hak menangguhkan ganti kerugian. Mengingat bahwa asal kepemilikan tanah adalah amanat maka pemerintah dalam menetap ganti kerugian dengan cara musyawarah.

Hal inilah sebenarnya yang menjadi tujuan hukum Islam yaitu maqasid assyar'iyah, menciptakan kemaslahatan bagi seluruh manusia. Dengan demikian kelihatan semakin jelas bahwa hukum Islam mempunyai konsep dan tujuan demi kepentingan masyarakat dan hukum Islam juga mencela dan sama sekali tidak mentolerir perbuatan warga masyarakat yang menimbulkan kerugian bagi sesamanya.

Prinsip yang berkaitan dengan penentuan ganti rugi bagi pengambilan tanah, antaranya ialah Ketika pemerintah akan mengambil tanah untuk kepntingan umum, maka harus ada proses pembayaran ganti rugi dengan pemiliknya. ${ }^{26}$

\section{c. Zaman Rasulullah SAW}

Rasulullah S.A.W, tatkala beliau Hijrah ke Madinah pada Tahun 1 Hijriah. Pada saat Rasulullah SAW dalam melanjutkan perjalanan ke Madinah, dengan menggunakan unta kemudian beliau berhenti (mendekam) di atas sebidang tanah milik dua orang anak yatim yang bernama Sahal dan Suhail, keduannya anak dari Amr bin Amarah di bawa pemelihraan As'ad ibnu Zarzarah. Tempat itu adalah penjemuran kurma milik dua orang anak laki-laki yatim itu. Beliau kemudian dipersilahkan oleh Abu Ayub Al Ansari untuk tinggal di rumahnya. Setelah

${ }^{26}$ Syekh Syaukat Hussain, Hak Asasi Manusia Dalam Islam, Gema Insani Press, Yogyakarta, 1996, hlm. 62 
beberapa bulan menetap di situ, beliau merencanakan untuk membangun mesjid. Tempat yang dipilih adalah bekas mendekamnya unta beliau. Rasulullah memanggil kedua anak yatim tersebut dengan maksud ingin membeli tanah itu guna tempat mendirikan masjid. Kedua anak itu bertahan dan tidak akan menjual tanahnya kepada Rasulullah SAW, kecuali hanya bersedia mewakafkannya. Akan tetapi beliau juga bertahan tidak mau mengambil begitu saja tanah itu, walaupun dalam bentuk wakaf. Beliau tidak mau mengambil tanah itu sebagai pemberian, tetapi beliau hendak membelinya. Pada akhirnya beliau berhasil membeli tanah itu dari tangan kedua anak yatim itu dengan harga yang disepakati yaitu, sebesar sepuluh dinar, dan membayarnya adalah Abu Bakar. ${ }^{27}$

\section{d. Zaman khalifah}

Begitu juga yang dilakukan oleh pemerintah Khalifah Umar tentang ganti rugi tanah (pembelian kembali), waktu itu Umar menyatakan suatu saat komunitas kaum muslim semakin banyak. Oleh karena itu, negara berhak untuk mengambil kembali tanah tersebut sebagai perbendaharaan guna memenuhi kebutuhan negara. Hal ini terjadi pada kasus Jabir Abdullah Bajali ketika Jabir dan sukunya akan dikirim ke Irak setelah meninggalkan panglima Abu Abayd, Umar berjanji kepada jabir, Jika mereka dapat menaklukan Irak, mereka akan diberikan seperempat tanah taklukan itu. Setelah pertempuran Qadisiyyah itu usai, janji tadi dipenuhi. Tetapi tiga tahun kemudian Umar meminta tanah itu kepada jabir, mengingat semakin bertambahnya kaum muslimin, dan Jabir mengembalikan tanah itu, Umar memberikan ganti kerugian sebesar 80 dinar yang di ambil dari harta milik Umar. ${ }^{28}$

Begitu juga ketika Umar bin Khatab diangakat sebagai Khalifah kedua dan jumlah penduduk semakin banyak, ia memperluas masjid dengan membeli rumah penduduk yang dekat rumah masjid. Kemudian ia menambah perluasan lagi dengan menambah bangunan penduduk yang berada disekitar masjid yang enggang untuk menjualnya. Umar kemudian memberikan harga tertentu, sehingga

\footnotetext{
27 Anwar Ibrahim, dkk., Status..., Loc., Cit.

${ }_{28}$ Irfan Mahmud Ra'ana, Sistem Ekonomi Pemerintahan Umar Bin Khatab, Alih bahasa Masarudin Djoel, Cetakan Pertama, Pustaka Firdaus, Jakarta, 1992, hlm. 38
} 
mereka mau menerimanya. Kasus yang sama juga terjadi pada Rabadah. Rabadah mempunyai padang rumput pribadi yang terletak dipingggir kota Madinah. Padang rumput tersebut digunakan untuk umum sebagai tempat pengembala kuda. Padang rumput itu sangat luas, bahkan kuda-kuda milik negara saja mencapai 4000 ekor yang digembalakan. Karena padang rumput itu tidak termaksud milik negara, maka Umar mengambil alih dengan membayar ganti rugi. ${ }^{29}$

Kadang-kadang tanah kebun diambil oleh negara jika dianggap amat penting untuk kemaslahatan umat. Ini terjadi terhadap tanah yang sebelumnya diberikan kepada suku Bajila dan Sawad. Umar mengambil kembali tanah tersebut dan memberikan ganti rugi sebesar 100 dirham kepada pemiliknya, uang itu milik umat yang tersimpan dalam kas negara. ${ }^{30}$

\section{Penutup}

Berdasarkan uraian di atas dapat ditarik kesimpulan, pertama, hukum Islam mengakui ada fungsi sosial hak atas tanah. Bahkan dapat ditegaskan bahwa Agama Islamlah pelopor awal atau pertama dari lahirnya fungsi sosial terhadap suatu benda. Hal ini dapat dilihat dari ajaran-ajaran Islam yang mengakui adanya hak orang lain atas benda yang dimiliki seseorang, termasuk dalam hal ini adalah tanah yang dimiliki seseorang. Dalam upaya memindahkan hak milik atas tanah sebagai milik perorangan menjadi hak milik bersama sebagai kepentingan umum, Islam mengedepankan konsep musyawarah untuk mufakat sebagai syarat mutlak dalam hal pengadaan tanah bagi kepentingan umum. Dalam al-Qur'an, ia menjadikannya sebagai suatu hal terpuji dalam kehidupan individu, keluarga, masyarakat dan negara, serta menjadi elemen penting dalam kehidupan umat, ia disebutkan dalam sifat-sifat dasar orang-orang beriman di mana keislaman dan keimanan mereka tidak sempurna kecuali dengannya. Dengan konsep musyawarah pelaksaan pengadaan tanah dapat mencapai keinginan antara kedua bela pihak, terutama keinginan untuk mendapat keadilan. Musyawarah dalam semua tahap pengadaan tanah tidak lain ialah "ia menduduki posisi yang sangat penting dalam menentukan hasil yang maksimal. Aspek musyawarah ini tanpa diikuti dengan

\footnotetext{
${ }^{29}$ Ibid., hlm. 38-39

${ }^{30}$ Ibid., hlm. 44
} 
kesadaran dan tekad yang besar untuk mewujudkannya, maka akan menyebabkan konflik yang berkepanjangan". Kedua, ganti kerugian dalam Islam dilakukan melalui proses jual beli yaitu pelaksanaan dilakukan dengan prinsip tawar menawar. Pembayaran ganti kerugian diberikan segera mungkin kecuali jika penerima hak menangguhkan ganti kerugian. Mengingat bahwa asal kepemilikan tanah adalah amanat maka pemerintah dalam menetap ganti kerugian dengan jalan musyawarah yang merujuk pada konsepsi jual beli dengan prinsip tawar menawar. Hukum Islam membenarkan pengambilan hak-hak atas tanah namun disertai dengan ganti rugi. Prinsip ganti rugi yang dipakai adalah hukum jual beli, oleh karena norma-norma dasar yang terdapat dalam Alquran dan hadis masih bersifat umum terutama dalam bidang mu'amalah. Menurut Islam yang dipakai adalah hukum jual beli, dapat dipastikan dalam hal transaksi dari jual beli menguntungkan masyarakat atau dapat disebutkan dengan istilah ganti untung.

\section{Daftar Pustaka}

\section{Buku}

A., Nurhayati, Studi Komparatif Ganti Rugi Atas Tanah Ditinjau Dari Prespektif Hukum Islam Dan Hukum Agraria Nasional (Studi Kasus Pelebaran Jalan Di Kota Medan).

Alim, Muhammad, Asas-Asas Negara Hukum Modern dalam Islam, Kajian Komprehensif Islam dan Ketatanegaraan, Cetakan I, LKIS, Yogyakarta, 2010.

Ash-Shiddieqy, Fuad Hasbi, ed., Falsafah Hukum Islam, PT. Pustaka Rizki Putra, Semarang, 2001.

Chairuman P, Hukum perjanjian dalam Islam, Sinar Grafika, Jakarta, 1994

Erwiningsih, Winahyu, Hak Menguasai Negara Atas Tanah, Cetakan 1, Universitas Islam Indonesia, Yogyakarta, 2009.

Guna Negara, Rakyat dan Negara, dalam pengadaan tanah untuk pembangunan, Cetakan Pertama, PT. Tatanusa, Jakarta, 2008.

Hussain, Syekh Syaukat, Hak Asasi Manusia Dalam Islam, Gema insani Press, Yogyakarta, 1996.

Ibrahim, Anwar, dkk., Status Tanah Masjid Harus Wakaf: Sudut Pandang Empiris dan Hukum Islam, Badan Wakaf Indonesia, Jakarta, 2012.

Limbong, Bernard, Politik pertanahan, Margaretha Pustaka, Jakarta, 2014. 
Lubis, Muhammad Yamin dan Rahim Lubis, Pencabutan hak, pembebasan, dan pengadaan tanah, Cetakan Pertama, CV. Mandar Maju, Bandung, 2011.

Poerwadharminta, WJS., Kamus Besar Bahasa Indonesia. Pusat Bahasa Indonesia), Balai Pustaka, Jakarta, 2003.

Ra'ana, Irfan Mahmud, Sistem ekonomi pemerintahan Umar bin Khatab, Alih bahasa Masarudin djoel. Cetakan Pertama, Pustaka Firdaus, Jakarta, 1992.

Salle, Amimuddin, Hukum pengadaan tanah untuk kepentingan umum, Ceatakan Pertama Kreasi Total Media, Yogyakarta, 2007.

Shihab, M. Quraish, Wawasan al-Quran, Mizan, Bandung, 1996.

Simorangkir, J.T.C., Edwin Rudy, S.H. dan Prasetyo, J.T. Kamus Hukum, Aksara Baru, Jakarta, 1980.

Soekanto, Soerjono dan Sri Mamujidji, penelitian normatif (Suatu tinjauan singkat), Cetakan Pertama, Rajawali Press, Jakarta, 2003

Suyuthi, Tarikh Khulafa: Sejarah Para Khilafah, Terjemahan oleh Ali Nurdin, Qisthi Press, Jakarta, 2017

Zakie, Mukmin, Kewenangan negara dalam pengadaan tanah bagi kepentingan umum di Indonesia dan Malasya, Cet. 2, Buku Litera, Yogyakarta, 2013.

\section{Jurnal dan Hasil Penelitian}

Abdullah, Dudung, "Musyawarah Dalam Al-Qur'an (Suatu Kajian Tafsir Tematik)" Al-Daulah, Vol. 3, No. 2, Desember 2014.

Roiqoh, Suruh, "Pengadaan Tanah Untuk Kepentingan Umum (Kajian Perbandingan Antara Hukum Islam dalam Konsep Maslaha Mursalah dan Undang-Undang Nomor 2 Tahun 2012)", Tesis pada Fakultas Hukum Universitas Islam Indonesia, Yogyakarta, 2013

Saufan, Akhmad, "Strategi dan Diplomasi Perang Rasulullah" Jurnal Lektur Keagamaan, Vol. 13, No. 1, 2015

Sohrah, "Konsep Syura dan Gagasan Demokrasi (Telaah Ayat-ayat Al-Qur'an)" AlDaulah, Vol. 4, No. 1, Juni 2015. 